\title{
Sustainable Applications for Utilizing Antimony Tailing Coarse Aggregate (ATCA) in Concrete: Characteristic of ATCA and Toxicity Risks of Concrete
}

\author{
Jianqun Wang ${ }^{1, *} \mathbb{C}$, Long $\mathrm{Li}^{1}$, Longwei Zhang ${ }^{1, *}, \mathrm{Bei} \mathrm{Li}^{1}{ }^{1}$, Renjian Deng ${ }^{1}$ and Defeng Shi ${ }^{2}$ \\ 1 Hunan Provincial Key Laboratory of Structures for Wind Resistance and Vibration Control, School of Civil \\ Engineering, Hunan University of Science and Technology, Xiangtan 411201, China; \\ lilong15173271886@163.com (L.L.); bei620bei@163.com (B.L.); 800912deng@sina.com (R.D.) \\ 2 School of Resources, Environment and Safety Engineering, Hunan University of Science and Technology, \\ Xiangtan 411201, China; 1020132@hnust.edu.cn \\ * Correspondence: jqw@hnust.edu.cn (J.W.); zhanglongwei@hnust.edu.cn (L.Z.)
}

Citation: Wang, J.; Li, L.; Zhang, L.; Li, B.; Deng, R.; Shi, D. Sustainable Applications for Utilizing Antimony Tailing Coarse Aggregate (ATCA) in Concrete: Characteristic of ATCA and Toxicity Risks of Concrete. Materials 2021, 14, 5480. https://doi.org/ 10.3390/ma14195480

Academic Editor: Yann Malecot

Received: 19 August 2021

Accepted: 18 September 2021

Published: 22 September 2021

Publisher's Note: MDPI stays neutral with regard to jurisdictional claims in published maps and institutional affiliations.

Copyright: () 2021 by the authors. Licensee MDPI, Basel, Switzerland. This article is an open access article distributed under the terms and conditions of the Creative Commons Attribution (CC BY) license (https:// creativecommons.org/licenses/by/ $4.0 /)$.
Abstract: In this research, the sustainable applications for utilizing antimony tailing coarse aggregate (ATCA) in concrete is investigated. Comprehensive verifications were performed by a series of experiments on the characteristic of ATCA and the toxicity risks of concrete. Firstly, a real case study of utilization of ATCA as a complete substitute for natural coarse aggregate (NCA) in high strength concrete was conducted. Then, chemical composition of ATCA was tested. It is demonstrated that the essential mineral is $\mathrm{SiO}_{2}$ and the lithology of ATCA is quartzite. The mechanical properties, coarse quality of ATCA, and NCA were studied and compared. The compressive strength, splitting tensile strength, and compressive elastic modulus of ATWR are $221.51 \mathrm{MPa}, 5.93 \mathrm{MPa}$, and $3.33 \times 10^{4} \mathrm{MPa}$, which are 1.31, 2.22, 1.40 times of that of NR, respectively. All of the quality control indices of ATCA meet the requirements of the current industry standards of China. Finally, the toxicity risks of ATCA concrete were investigated. It is illustrated that the leaching of main heavy metals including Sb, As, $\mathrm{Hg}, \mathrm{Pb}, \mathrm{Cd}$, and $\mathrm{Zn}$ in the ATCA concrete under different $\mathrm{pH}$ conditions are below the regulatory limits. The utilization of antimony tailing has significant environmental and economic benefits.

Keywords: antimony tailing waste rock (ATWR); antimony tailing coarse aggregate (ATCA); natural coarse aggregate (NCA); chemical composition; mechanical properties; quality of coarse aggregate (CA); leaching test

\section{Introduction}

Antimony ( $\mathrm{Sb}$ ) is a metalloid element belonging to Group 15 of the periodic table, naturally occurring in the Earth's crust [1]. Sb is usually alloyed with other kind of metals and widely used in different industrial fields [2,3]. Due to the excellent metallogenic environment to form large and super large deposits, China is the country with the largest reserves of antimony mineral resources [4,5]. The Xikuangshan (XKS) Sb mine, located near Lengshuijiang City, Hunan Province, China, is the largest Sb mine in the world. Large-scale mining and smelting activities have occurred for over 120 years in this area, where it has for a long time been famously named the "World Antimony Capital" [6-8].

However, $\mathrm{Sb}$ and its compounds are considered to be hazardous to human health, causing degradation in liver and low blood sugar $[9,10]$. In the processes of mining and smelting, large quantities of $\mathrm{Sb}$ are released to the surrounding environment [11-13]. The mined antimony ore is generally broken into crushed stones with a certain particle size and used for artificial beneficiation. Plenty of low-grade antimony ore is selected and abandoned as antimony tailing waste rock (ATWR) [14]. Some of the ATWRs are used for backfilling, and the others are stored in a tailing dam, or abandoned in the open air nearby the mining area $[15,16]$. As illustrated in Figure 1, during the field investigation, the authors 
found that there were millions of tons of ATWRs in XKS. These ATWRs not only occupy valuable land resources but also induce significant pollution to the environment $[17,18]$.

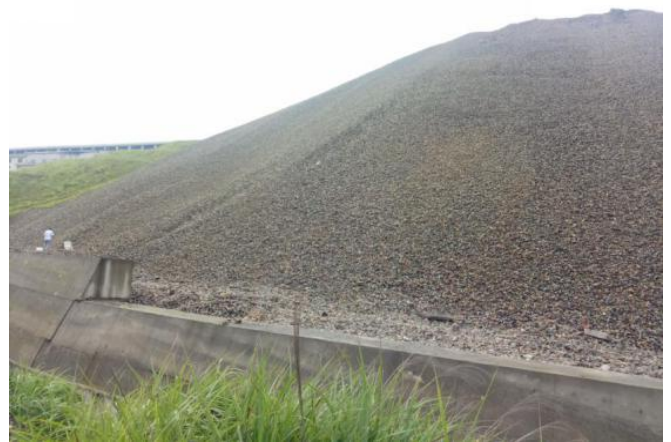

(a)

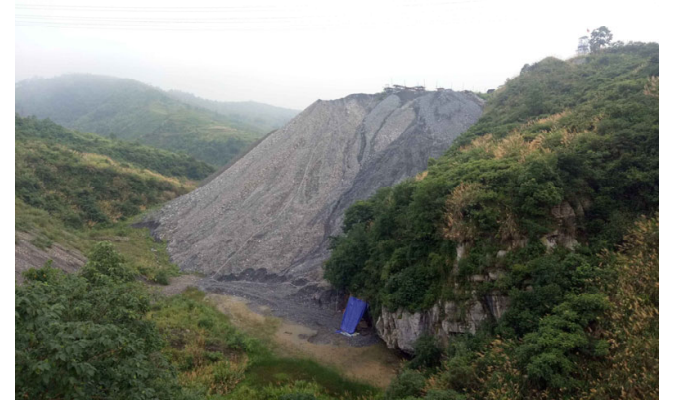

(b)

Figure 1. The ATWRs in XKS: (a) ATWRs occupy valuable land resource; (b) ATWRs destroy the ecological environment.

In recent years, the green and sustainable production of concrete receives much attention [19-21]. Aggregate continues to be increased as more concrete is consumed all over the world [22,23]. Since stone and sand are non-renewable resources, the traditional ways to produce aggregate is not sustainable [24,25]. Utilizing ore tailings as valuable concrete raw materials is a feasible treating method, which has received increasing attention for the past years [26-28]. Gayana and Chandar proposed that some waste materials, such as iron ore tailings, recycled concrete aggregate, glass, plastics, and quartz sandstone, could be utilized as replacement for coarse aggregates in concrete [29]. Zhao et al. investigated the utilization of iron ore tailings as fine aggregate in ultra-high performance concrete, the tailings were characterized by techniques like SEM, XRD, and nanoindentation [30]. Lv et al. reported that the iron tailings could be utilized as a complete replacement of normal aggregates in dam concrete. It was demonstrated that iron tailing concrete had a higher specific gravity and water consumption than that of natural aggregate (NA) concrete due to the different characteristic of iron tailing aggregate [31]. Vijayaraghavan et al. investigated the effect of using alternatives for both fine and coarse aggregates with copper slag, iron slag, and recycled concrete aggregate with various proportions of mix. Based on the characteristics of coarse aggregates and the mechanical properties of the concrete samples, they found that $40 \%$ of copper slag, $40 \%$ iron slag, and $25 \%$ of recycled concrete aggregate possessed more strength than the conventional concrete mix [32]. Thus, it can be concluded that the performance concrete is affected by the characteristic of tailing aggregate. We proposed utilizing antimony tailing coarse aggregate (ATCA) as a complete substitute for natural coarse aggregate (NCA) in high strength concrete in previous work, providing a new way for utilizing ATWRs [33], while the characteristic of ATCA has not been reported.

Besides, the toxicity risks of heavy metals must be taken into consideration when the wastes are used as building materials [34,35]. The leached out heavy metal contents should be low enough to meet the requirements [36,37]. Barna et al. reported leaching assessment of road materials containing primary lead and zinc slags. They found that the release of $\mathrm{Pb}$ and $\mathrm{Zn}$ was controlled by the $\mathrm{pH}$ of the leachate [38]. Zhou et al. evaluated the toxicity risks of lead-zinc sulfide tailing-based construction materials with sulfuric acid and nitric acid method, by which the specimens were leached in a mixed acid solution with a pH of $3.20 \pm 0.05$ [39]. Onuaguluchi and Eren reported the toxic metal immobilization properties of copper tailings as a potential additive in concrete. The leaching of heavy metals was evaluated by toxicity characteristic leaching procedure with leaching medium of glacial acetic acid and deionized water [40]. In order to better understand the leaching performance of tailing concrete, the leaching medium should cover different acid-based conditions. 
Science coarse aggregate (CA) is the largest component of high strength concrete, significantly affecting the performance, it is necessary to investigate the characteristic of ATCA in tailing concrete. Furthermore, the toxicity risks of ATCA concrete should be evaluated to ensure the concrete is harmless to the environment. The aim of this study is to investigate the characteristic of ATCA and the leaching performance of ATCA concrete based on the previous work. A series of experiments was performed, such as chemical composition and mechanical properties of ATWRs, coarse quality of ATCA, and the toxicity risks of ATCA concrete, which were tested and discussed in the present work.

The rest of this paper is organized as follows. Section 2 introduces the background of a real case study. Section 3 describes the main chemical composition of ATCA. Section 4 illustrates the mechanical properties of ATWR and compared with natural rock (NR). Section 5 shows the quality of ATCA and compared with NCA. Section 6 discusses the toxicity risks of ATCA concrete. Finally, Section 6 concludes the article and gives some recommendations for future work.

\section{Background of a Real Case Study}

The construction of the Long-lang highway project, which is nearby XKS and located in South China's Loudi City, Hunan Province, is chosen as a real case in the present work. As illustrated in Figure 2, the project is $74 \mathrm{~km}$ large, including 14 bridges with a total length of $5.1 \mathrm{~km}$. All of the girders of the superstructures of the bridges use C50 concrete, which consumes about $1,330,000 \mathrm{~m}^{3}$ of NCA. However, the NCA of the nearby quarry is not suitable for C50 concrete, and the qualified supplier is $52 \mathrm{~km}$ to the site. After our investigation, we found that the compressive strength of the ATWRs from XKS met the requirements. Moreover, the distance from XKS to the project is only $20 \mathrm{~km}$. Considering the above issues, the entire C50 concrete is intended to prepare with ATCA as a complete replacement of NCA. Using ATCA can not only provide a new method for the treatment of antimony tailing, but also solve the problem of shortage of raw materials for the project and create huge economic benefits.

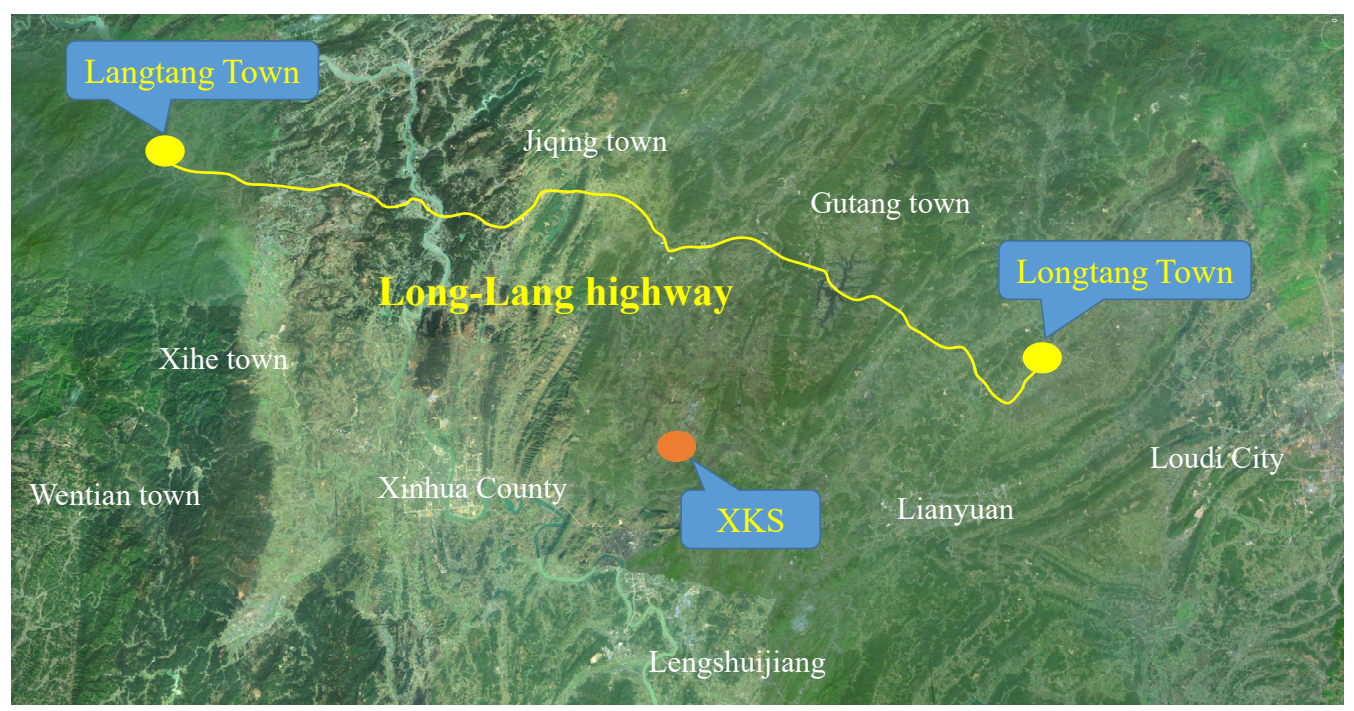

Figure 2. The location of Long-lang highway project and XKS.

In this part, the investment and environmental benefits are discussed by using ATCA concrete. The cost for ATCA administration, reclaiming, and transportation are respectively saving $90 \%$ ( $¥ 0.8$ yuan, Chinese currency), 85\% ( $¥ 27$ yuan), and $61 \%$ ( $¥ 25$ yuan) per cubic meter compared with NCA. The cost saving of direct investment resulting from ATCA can be obtained with the following equation,

$$
\Delta C_{A T}=V_{A T} \times\left(\Delta A_{A T}+\Delta R_{A T}+\Delta T_{A T}\right)
$$


where $\Delta C_{A T}$ (yuan) represents the cost saving of direct investment, $V_{A T}$ is the ATCA total volume consumption, $\Delta A_{A T}$ (yuan), $\Delta R_{A T}$ (yuan), and $\Delta T_{A T}$ (yuan) are respectively the saving cost for ATCA administration, reclaiming, and transportation. Based on the investigation, it is conservatively estimated that the ATCA can save $79 \%$ of the cost (¥70.224 million yuan, \$10.871 million dollars, the exchange rate between US dollar and Chinese RMB is 6.46 on 8 September 2021).

In addition, the use of ATCA reduces about $15,000 \mathrm{~m}^{2}$ land occupation for stacking ATWRs. It is very conducive to control the solid waste pollution on the environment and protect the ecology. Therefore, the utilization of ATCA as a complete substitute for NCA in concrete shows a great potential for economic and environmental benefits.

\section{The Main Chemical Composition of ATCA}

\subsection{Sampling}

The test sample was obtained by the five-point sampling method in the antimony waste ore stacking area in XKS. The stacking area is approximately a rectangle, divided into four areas by diagonals, and the sampling points are distributed at the intersection and quarter points of the diagonals. A total of $400 \mathrm{~kg}$ ATWRs were collected from each sampling point, $1 \mathrm{~m}$ from the upper surface. The collected ATWRs were mixed together and brought back to the laboratory. Some were processed into specimens for rock mechanical performance testing. The rest were crushed into ATCA, of which the particle size was 5-20 mm, used for chemical composition analysis, aggregate quality testing, and preparing for ATCA concrete performance experiment.

\subsection{Experiment Methodology}

X-ray fluorescence spectrometer (XRD, D8 Advance, BRUKER AXS GMBH, Karlsruhe, Germany) was used to analyze the chemical composition ATCA. Polarizing microscope (Leica DM2500P, Leica instruments (China) Co., Ltd., Beijing, China) was used to analyze the mineral composition of the test sample.

\subsection{Results and Discussion}

The chemical composites of ATCA is provided in Table 1. Polarizing microscope and X-ray diffraction (XRD) analysis illustrated that the essential mineral was quartz $\left(\mathrm{SiO}_{2}\right)$, and the subordinate mineral contained kaolinite, pyrophyllite, muscovite, and montmorillonite (Figure 3). It is shown that ATWR is a massive block structure and is mainly composed of quartz.

Table 1. The test result of main chemical composition of ATCA (\%).

\begin{tabular}{|c|c|c|c|c|c|c|c|c|c|c|c|c|}
\hline Chemical Composition & $\mathrm{SiO}_{2}$ & $\mathrm{Al}_{2} \mathrm{O}_{3}$ & $\mathrm{Fe}_{2} \mathrm{O}_{3}$ & $\mathrm{CaO}$ & $\mathrm{MgO}$ & $\mathrm{K}_{2} \mathrm{O}$ & $\mathrm{Na}_{2} \mathrm{O}$ & $\mathrm{TiO}_{2}$ & $\mathrm{MnO}$ & $\mathrm{FeO}$ & $\mathrm{P}_{2} \mathrm{O}_{5}$ & LOI \\
\hline wt. $\%$ & 88.78 & 3.86 & 0.98 & 0.61 & 0.11 & 0.42 & 0.02 & 0.17 & 0.03 & 0.27 & 0.04 & 2.98 \\
\hline
\end{tabular}

Figure 4 illustrates mineral composition of ATWR. According to the crystal size and the mosaic relationship between each other, the quartz in the samples can be divided into early and late stage, and the early stage is the main one. The early stage of quartz $\left(Q_{1}\right)$ is closely inlaid to form a dense aggregate with clear boundaries. Most of the grains are concavo-convex and suture-shaped. The crystal size is relatively uniform, generally varying from $20 \mu \mathrm{m}$ to $150 \mu \mathrm{m}$. A small amount of chalcedony is distributed between grains. The late stage of quartz $\left(\mathrm{Q}_{2}\right)$ is composed of fine vein-like aggregates, filling along the rock fissures (red dotted area). The vein wall of the late stage of quartz $\left(\mathrm{Q}_{2}\right)$ is relatively straight, and the width of the vein varies from 100 to $300 \mu \mathrm{m}$, and the particle size of late stage quartz varies from 30 to $100 \mu \mathrm{m}$. The lithology of ATWR is quartzite. According to rock characteristics, it can be inferred that ATWR has good mechanical properties and can be used as CA for high strength concrete. 


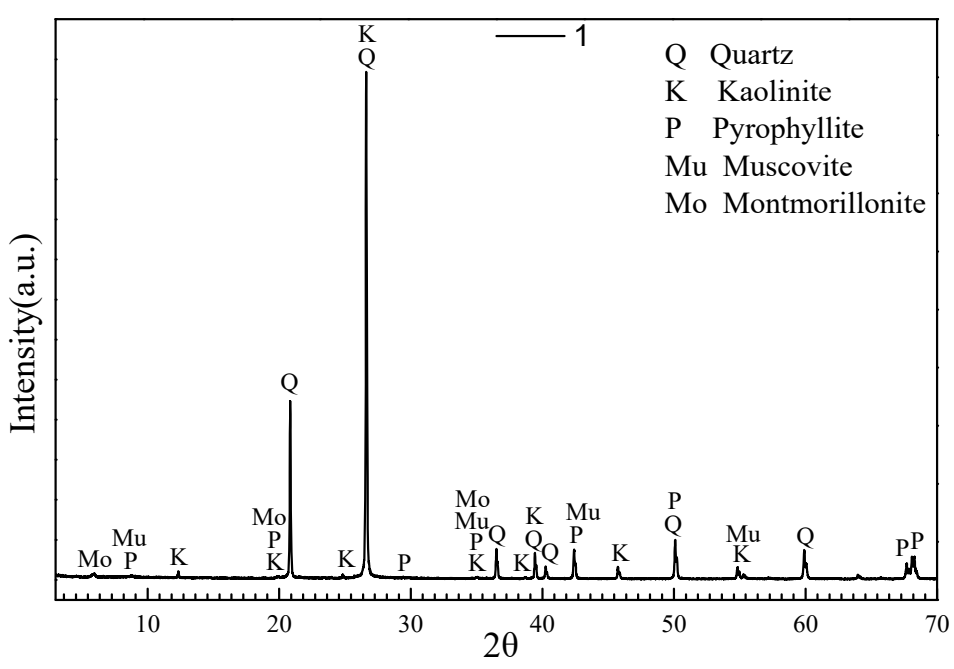

Figure 3. XRD pattern of ATWR.

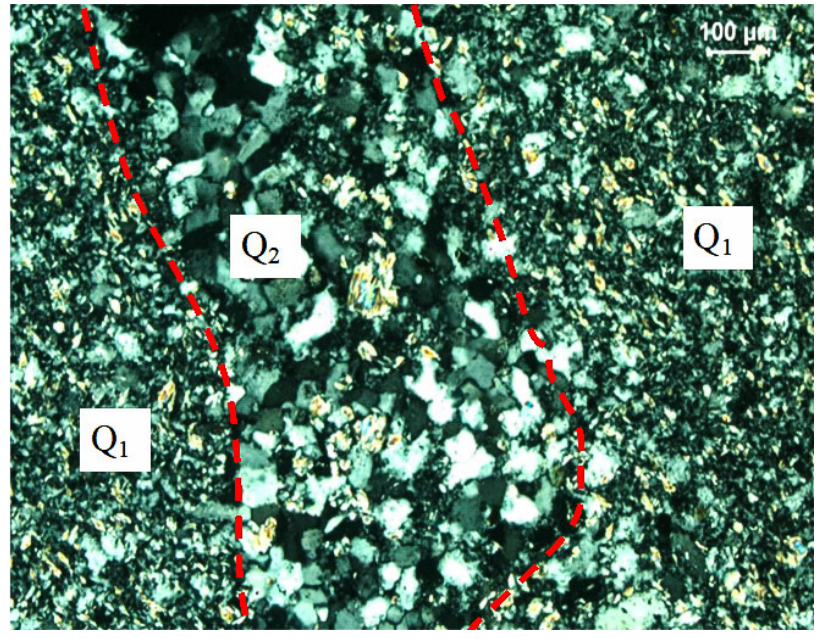

Figure 4. Mineral composition of ATWR. $\left(Q_{1}\right.$ represents the early stage of quartz, and $\mathrm{Q}_{2}$ represents the late stage of quartz).

\section{Rock Mechanical Properties}

\subsection{Experimental Design}

The mechanical properties, such as uniaxial compressive strength, splitting tensile strength, and elastic modulus are the most important geotechnical parameters for intact rocks $[41,42]$. Since CA is the skeleton of concrete, the mechanical properties of rock affects the mechanical behaviors of concrete. In this paper, uniaxial compressive strength, splitting tensile strength, and elastic modulus are tested according to JTG E41-2005 [43].

To better investigate the rock mechanical properties of ATWR, NR form the qualified supplier for NCA, mentioned in Section 2, was prepared as well. The sizes of the specimens used for the experimental study are listed in Table 2.

Table 2. Dimensions of the specimens for rock mechanical properties.

\begin{tabular}{cccc}
\hline No. & Experiments & Sample Shape & Sample Size (mm) \\
\hline 1 & Cubic compressive strength & Cube & $70 \times 70 \times 70$ \\
2 & Splitting tensile strength & Cylinder & $\varnothing 50 \times 50$ \\
3 & Prism compressive strength & Cylinder & $\varnothing 50 \times 100$ \\
4 & Elasticity modulus & Cylinder & $\varnothing 50 \times 100$ \\
\hline
\end{tabular}




\subsection{Results and Discussions}

\subsubsection{Compressive Strength of Cubic Samples}

The compressive strength of ATWR was $221.51 \mathrm{MPa}$, while the measured value of NR was $169.52 \mathrm{MPa}$. Since the lithology of ATWR is quartzite, its compressive strength is much higher than that of NR. There was a clear cracking sound as the ATWR sample was crushed, while the cracking sound of NR was relatively low.

The loading process of both groups of specimens exhibits three stages, i.e., elastic stage, crack developing stage, and failure stage. While the failure modes of the two kinds of rock samples are obviously different, as illustrated in Figure 5. The crushing plane passed along the planar, which could be represented by its inclination angle. According to the experimental data, the angle of ATWR and NR are about $58^{\circ}$ and $54^{\circ}$, respectively. Actually, the angle can be derived by the following equation,

$$
\beta=\frac{\pi}{4}+\frac{\phi}{2}
$$

where $\beta$ is the angle between normal of crushing surface and loading axis; $\phi$ is the friction angle of testing samples, as shown in Figure 5b,d. According to the previous work [44], the higher compressive strength of samples is, the more sliding surfaces. Such phenomenon appears for the strength of ATWR is higher than that of NR.

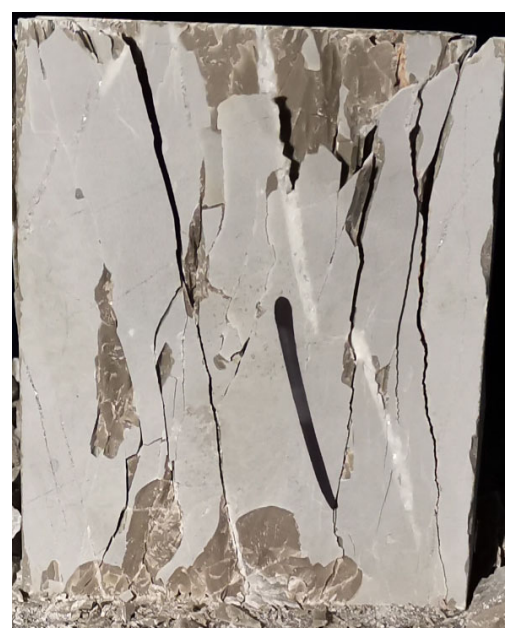

(a)

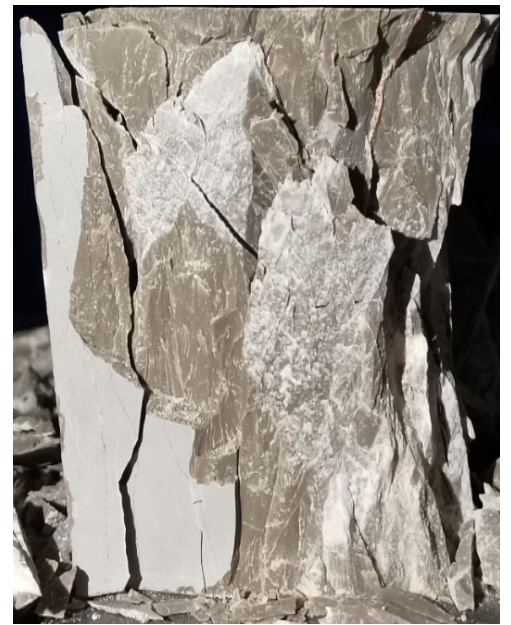

(c)

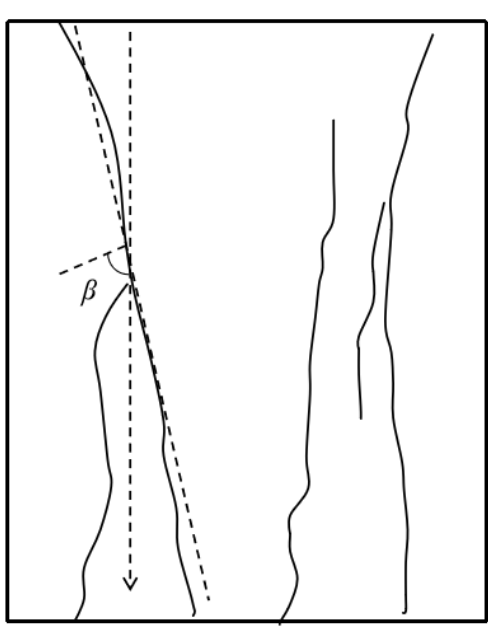

(b)

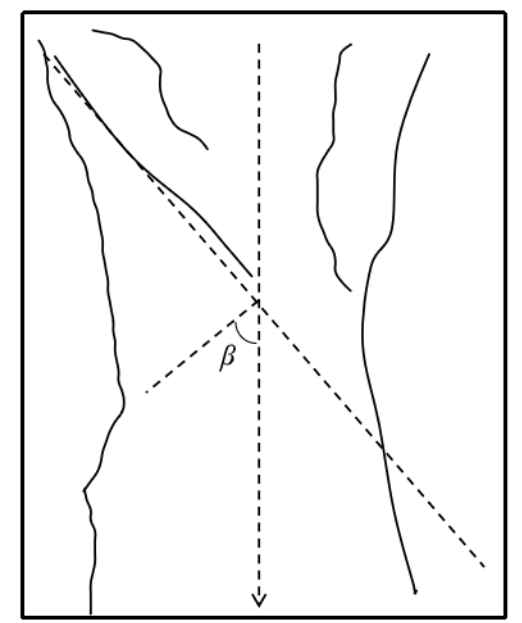

(d)

Figure 5. The failure modes of the two kinds rock samples: (a) the failure mode of ATWR; (b) the crushing plane of ATWR; (c) the failure mode of NR; (d) the crushing plane of NR. 


\subsubsection{Splitting Tensile Strength}

There are two methods to determine the tensile strength of rock: direct tension test method and indirect tension test method. For the direct tension method, the specimen production is more difficult and the experimental technology is more complicated. Therefore, the indirect tension method is generally used for testing. The failure load of the rock is tested based on the splitting method, and the splitting tensile strength is obtained by conversion.

As shown in Figure 6, splitting tensile strength is tested by a rock mechanics test system (RMT-150C type, Wuhan Institute of geotechnical mechanics, Chinese Academy of Sciences, Wuhan, China). The splitting tensile strength of ATWR is $5.93 \mathrm{MPa}$, of which $2.7 \%$ is compressive strength. While the splitting tensile strength of NR is $2.67 \mathrm{MPa}$, of which only $1.6 \%$ is compressive strength. The splitting tensile strength of ATWR is two times higher than that of NR's.

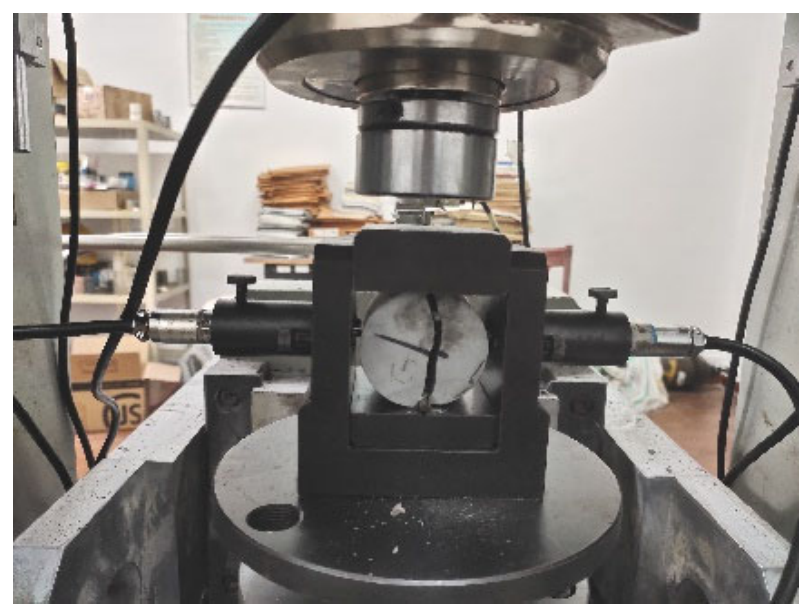

Figure 6. The splitting tensile strength experiment.

\subsubsection{Compressive Elastic Modulus}

As illustrated in Figure 7, the compressive elastic modulus is tested by the RMT-150C type rock mechanics test system as well. The stress-strain curve is shown in Figure 8. The compressive elastic modulus of ATWR is $3.33 \times 10^{4} \mathrm{MPa}$, while the measured value of NR is $2.38 \times 10^{4} \mathrm{MPa}$. The elastic modulus of NR is $71.5 \%$ of ATWR's. Since compressive strength is an adequate index for mechanical properties, a close relationship exists between compressive strength and elastic modulus of the two kinds of samples.

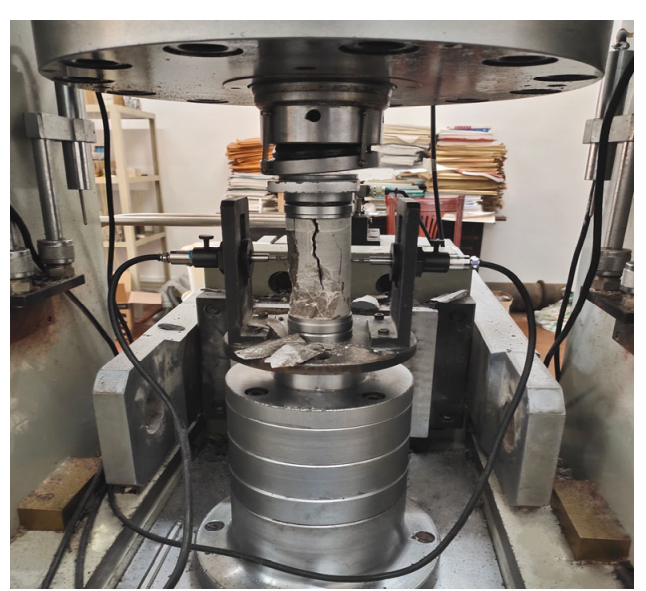

(a)

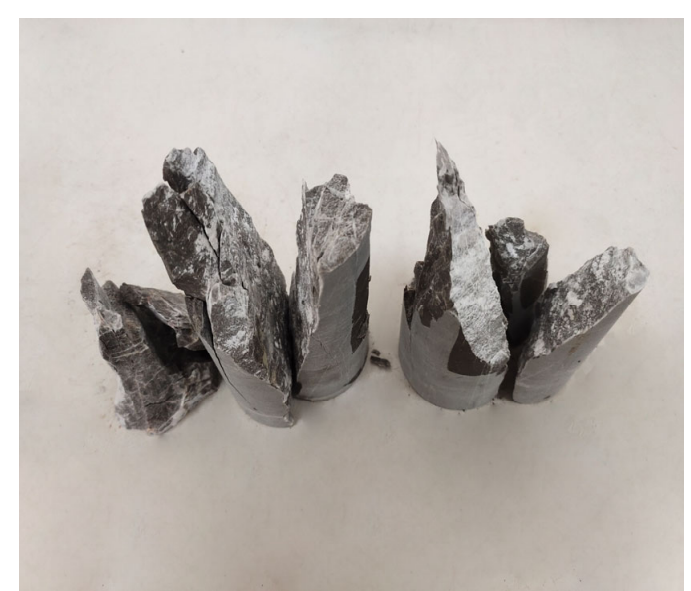

(b)

Figure 7. The compressive elastic modulus experiment: (a) test instrument; (b) failure mode. 


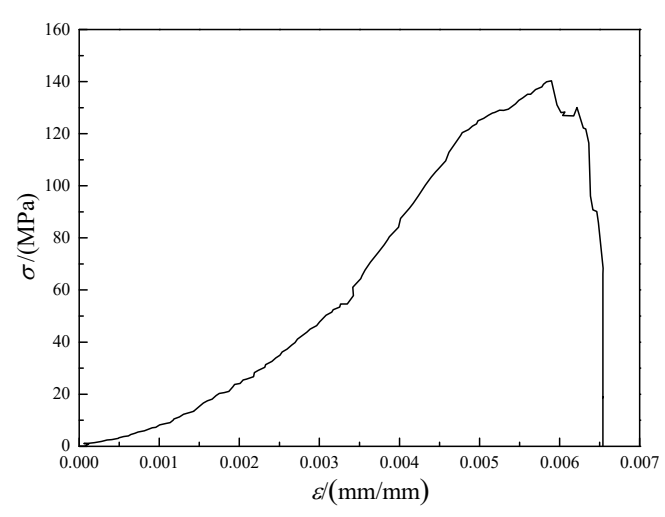

(a)

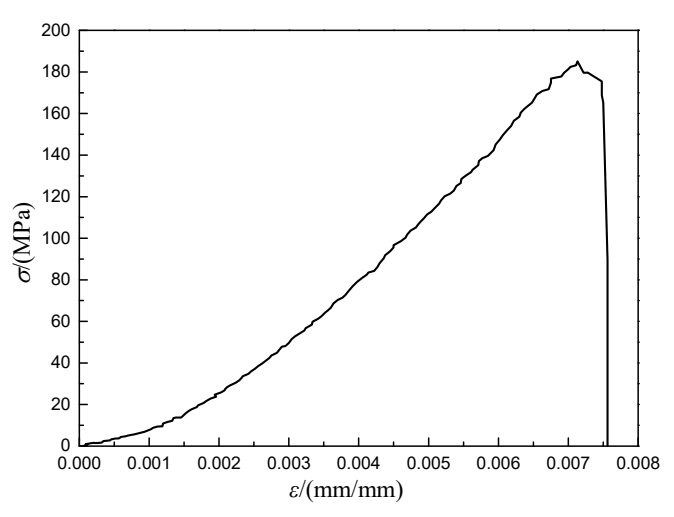

(b)

Figure 8. The test result of elastic modulus: (a) NR; (b) ATWR.

In this section, the mechanical behaviors such as cubic compressive strength, splitting tensile strength, and compressive elastic modulus of the two kinds of samples were tested simultaneously. The results show that the cubic compressive strength, splitting tensile strength, and compressive elastic modulus of ATWR are 1.31, 2.22, 1.40 times of that of NR's. Therefore, the mechanical behavior of ATWR is superior to that of NR. This further shows that the ATWR possesses excellent mechanical property for the lithology of is quartzite and that it is very suitable for high strength concrete. It can be inferred that the ATCA as a substitution for NCA possesses perfect physical and mechanical properties. In order to further study the feasibility of ATCA for concrete, the quality of ATCA is investigated in the next section.

\section{The Quality of ATCA}

\subsection{Experiment Methodology}

To ensure the mechanical property [45] and durability [46] of the bridge structure, the quality of concrete materials should be guaranteed. Since the performance of concrete is directly affected by CA, the material quality of ATCA should meet the specification requirements. The ATWRs were sampled and crushed into CA, and the particle size was 5-20 mm. The NCA was obtained from the nearest qualified supplier mentioned in Section 2. The material quality of ATCA and NCA was tested simultaneously according to Chinese National Standard GB/T 14685-2011 [47]. The experiment includes gradation, density, water absorption, alkali silica reaction (ASR), needle-flake content, firmness, crushing value, abrasion resistance, dust content, and clay lump content.

\subsection{Gradation}

The sieving method was used to determine the graduation of ATCA and NCA. The gradation curve is illustrated in Figure 9, which shows that ATCA and NCA distribute within the scope of $5-20 \mathrm{~mm}$. Therefore, the ATCA is continuously graded aggregate, conforming to the requirement of the standard.

\subsection{Density Water Absorption and ASR}

The density and water absorption of CA are key indices of material quality, which indirectly reflects the open porosity of the aggregate. The lower water absorption of the aggregate means lower open porosity, higher density, and better working performance and durability behavior for the concrete.

The apparent density, gross bulk density, loose bulk density, void ratio, and water absorption are listed in Table 3. It is demonstrated that all indices meet the specification requirements. As per the code, if the water absorption is less than $1 \%$, the index is classified as grade I, and $1-2 \%$ is classified as grade II. The results of water absorption of ATCA and NCA are respectively $0.7 \%$ and $0.8 \%$, which are both classified as grade I. The apparent density, gross bulk density of ATCA are higher than those of NCA's. While 
the loose bulk density, void ratio and water absorption of ATCA are lower than those of NCA. Nevertheless, it is explicitly found that the difference in all of the indices between ATCA and NCA are very small. It can be inferred that the influence of ATCA on concrete workability performance, such as slump, apparent density and air content, is negligible.

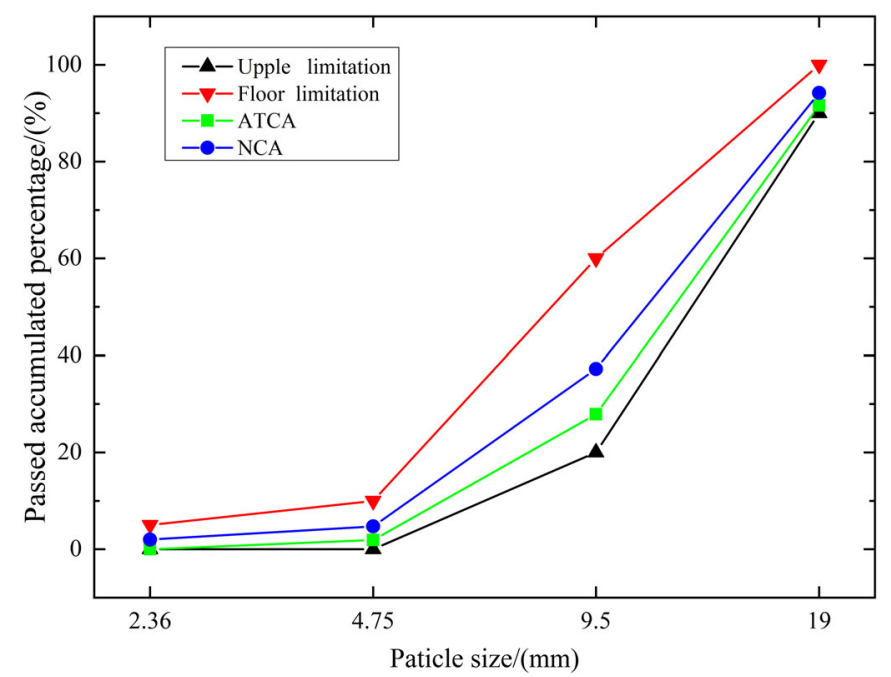

Figure 9. Gradation curve of ATCA and NCA.

Table 3. The test results of density, water absorption and ASR.

\begin{tabular}{|c|c|c|c|c|c|c|}
\hline Description & $\begin{array}{l}\text { Apparent Density } \\
\left(\mathrm{kg} / \mathrm{cm}^{3}\right)\end{array}$ & $\begin{array}{c}\text { Gross Bulk } \\
\text { Density }\left(\mathrm{kg} / \mathrm{cm}^{3}\right)\end{array}$ & $\begin{array}{c}\text { Loose Bulk } \\
\text { Density }\left(\mathrm{kg} / \mathrm{cm}^{3}\right)\end{array}$ & $\begin{array}{c}\text { Void } \\
\text { Ratio (\%) }\end{array}$ & $\begin{array}{c}\text { Water } \\
\text { Absorption (\%) }\end{array}$ & $\begin{array}{r}\text { ASR } \\
(\%)\end{array}$ \\
\hline ATCA & 2653 & 2592 & 1497 & 38.26 & 0.7 & 0.80 \\
\hline NCA & 2608 & 2533 & 1512 & 38.93 & 0.8 & 0.71 \\
\hline Regulatory limits & $\geq 2500$ & / & $\geq 1350$ & $<47$ & Grade I & $<1$ \\
\hline
\end{tabular}

In order to evaluate the ASR of ATCA, the alkali activity experiment was conducted. ATCA and NCA specimens with dimension of $25 \times 25 \times 280 \mathrm{~mm}$ were prepared for the experiment. For 14 days, all samples were placed in the $\mathrm{NaOH}$ solution, of which the concentration was $1 \mathrm{~mol} / \mathrm{L}$, and the temperature was $(80 \pm 2){ }^{\circ} \mathrm{C}$. The length of the sample was measured, by which the expansion rate of length was calculated and the alkali activity of aggregate was evaluated. The expansion rates of ATCA and NCA specimens are $0.71 \%$ and $0.80 \%$, respectively, which are both less than $1 \%$ of the standard required.

\subsection{Other Indices of Material Quality}

Other indices of material quality, including needle-flake content, firmness, crushing value, abrasion resistance, dust content, and clay lump content were test in this subsection. As per the code, all of the indices are classified into three grades, of which the ranges are shown in Table 4.

Table 4. The test results of the quality of ATCA and NCA.

\begin{tabular}{|c|c|c|c|c|c|c|c|c|c|c|c|c|c|}
\hline \multirow{2}{*}{\multicolumn{2}{|c|}{ Description }} & \multicolumn{2}{|c|}{$\begin{array}{l}\text { Needle-Flake } \\
\text { Content }\end{array}$} & \multicolumn{2}{|c|}{ Firmness } & \multicolumn{2}{|c|}{$\begin{array}{l}\text { Crushing } \\
\text { Value }\end{array}$} & \multicolumn{2}{|c|}{$\begin{array}{l}\text { Abrasion } \\
\text { Resistance }\end{array}$} & \multicolumn{2}{|c|}{ Dust Content } & \multicolumn{2}{|c|}{$\begin{array}{l}\text { Clay Lump } \\
\text { Content }\end{array}$} \\
\hline & & Result & Grade & Result & Grade & Result & Grade & Result & Grade & Result & Grade & Result & Grade \\
\hline \multirow{3}{*}{\multicolumn{2}{|c|}{ Classification }} & $\leq 5$ & I & $\leq 5$ & I & $\leq 10$ & I & $\leq 28$ & I & $\leq 0.5 \%$ & $\mathrm{I}$ & 0 & I \\
\hline & & $\leq 15$ & II & $\leq 8$ & II & $\leq 20$ & II & $\leq 30$ & II & $\leq 1.0 \%$ & II & $\leq 0.5 \%$ & II \\
\hline & & $\leq 25$ & III & $\leq 12$ & III & $\leq 30$ & III & $\leq 35$ & III & $\leq 1.5 \%$ & III & $\leq 0.7 \%$ & III \\
\hline \multirow{2}{*}{$\begin{array}{l}\text { Test } \\
\text { results }\end{array}$} & ATCA & $4.50 \%$ & I & $3.00 \%$ & I & $9.20 \%$ & I & $18.0 \%$ & I & $0.40 \%$ & I & $0.10 \%$ & II \\
\hline & NCA & $3.50 \%$ & I & $3.60 \%$ & I & $14.80 \%$ & II & $24.5 \%$ & I & $0.72 \%$ & II & $0.18 \%$ & II \\
\hline
\end{tabular}


The content of needle-flake particles was tested by a needle-flake gauge, divided into three grades. As illustrated in Table 4, if the needle-flake content is less than or equal to $5 \%$, it is classified as grade I, $5-15 \%$ is classified as grade II, and $15-25 \%$ is classified as grade III. The results of tested needle-flake content of ATCA and NCA are respectively $4.5 \%$ and $3.5 \%$, which are both classified as grade I.

The sample was soaked in a saturated sodium sulfate solution. After five cycles of immersion and drying, the mass loss percentage was measured and the firmness was determined. The results of the mass loss percentage of ATCA and NCA are respectively $3.0 \%$ and $3.6 \%$, which are both classified as grade I according to Table 4 .

The crush value refers to the ability of CA to resist crushing and indirectly reflects the strength performance of CA. Pressure was applied to the sample by a press, and the mass percentage of the sieved fine material after pressure was used to determine the crushing value. The results of mass percentage of the sieved fine material of ATCA and NCA is $9.2 \%$ and $14.8 \%$, which are classified as grade I and grade II, respectively.

The abrasion resistance of CA was tested by the Los Angeles method. The mass loss of ATCA and NCA is $18.0 \%$ and $24.5 \%$, respectively. As per the code, the abrasion resistance of ATCA and NCA are both classified as grade I.

The dust content was determined by testing the weight of particles with a particle size of less than $0.075 \mathrm{~mm}$ in the CA. The results of the dust content of ATCA and NCA is $0.4 \%$ and $0.72 \%$, which are classified as grade I and grade II, respectively.

Moreover, the clay lump content was determined by testing the weight of clay lump with a particle size of more than $2.36 \mathrm{~mm}$ in the CA. The results of the clay lump content of ATCA and NCA is $0.1 \%$ and $0.18 \%$, which are all classified as grade II according to Table 4 .

\subsection{Discussion}

The experiment results are summarized and showed in Tables 3 and 4. It is demonstrated that all of the quality indices of ATCA and NCA meet the requirements of the current industry standards of China.

The results of water absorption and firmness of ATCA are superior to NCA, therefore, it can be inferred that ATCA concrete has better frost resistance. The alkali activity of samples seems increased for ATCA specimens. However, the difference is not significant and can be neglected. The tested results of firmness, crushing value, and abrasion resistance of ATCA are superior to that of NCA. ATCA possesses excellent abrasion resistance performance, thus it can be inferred that ATCA may be applied in concrete pavement. It is demonstrated that the compressive performance of ATCA is significantly better than that of NCA, which is completely consistent with the strength test results of the material. The dust content and clay lump content of ATCA are lower than that of NCA, and it is beneficial to enhance the bonding performance between ATCA and mortar. However, the needle-flake content of ATCA is higher than that of NCA. The factor for higher needle-flake content of ATCA could be attributed to higher compressive strength of ATCA, which tends to produce needle-like particles when crush into CA.

\section{The Leaching Test of ATCA Concrete}

\subsection{Experiment Methodology}

The toxicity characteristic leaching experiment was conducted to evaluate the concentration of heavy metals from ATCA concrete and ensure that the concrete was harmless to the environment. The static soaking method was used to analyze the dissolution and release of the main heavy metals including $\mathrm{Sb}, \mathrm{As}, \mathrm{Hg}, \mathrm{Pb}, \mathrm{Cd}$, and $\mathrm{Zn}$ in the ATCA concrete under different $\mathrm{pH}$ conditions according to GB 30770-2014 [48].

A total of seven batches of leaching tests were carried out to simulate the leaching of heavy metal from ATCA concrete soaked in different $\mathrm{pH}$ solutions. Sulfuric acid or sodium hydroxide solution were used to adjust the $\mathrm{pH}$ values of the soaking solution at 4, 5, 6, 7, 8, 9 , and 10. 
Table 5 shows the mixture proportions for the cubic concrete block. Ordinary Portland cement with a strength class of 42.5, ATCA made from the sampled ATWRs, and manufactured sand were used in the experiment. Poly-carboxylate superplasticizer was added to concrete with $0.2 \%$ by the weight of cementitious materials.

Table 5. Mix ratio of the concrete (unit: $\mathrm{kg} / \mathrm{m}^{3}$ ).

\begin{tabular}{ccccc}
\hline Cement & ATCA & Manufactured Sand & Water & Superplasticizer \\
\hline 485 & 1047 & 758 & 160 & 5.8 \\
\hline
\end{tabular}

\subsection{Results and Discussion}

The concentration of the heavy metal was measured every two days and the test lasted for 14 days. The results are shown in Figure 10. It should be noted that only the test results of $\mathrm{Sb}, \mathrm{As}$, and $\mathrm{Hg}$ are shown in the figure. Since the test results of several other heavy metal elements such as $\mathrm{Cd}, \mathrm{Pb}$, and $\mathrm{Zn}$ are quite small and lower than $0.001 \mathrm{mg} / \mathrm{L}$, which meet the specification requirements. The results are not presented here.

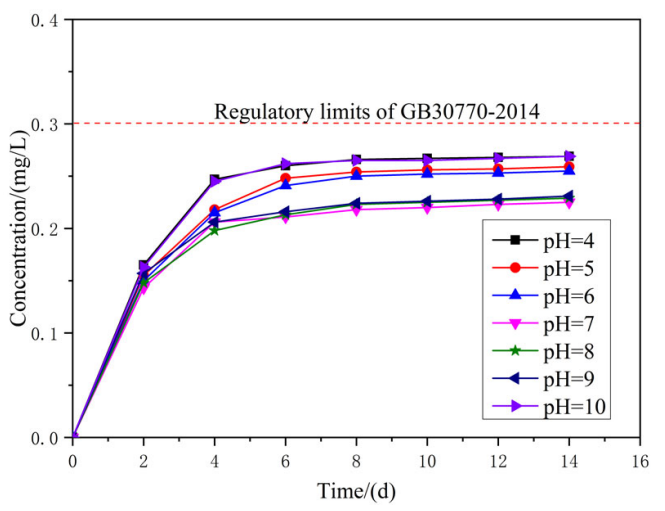

(a)

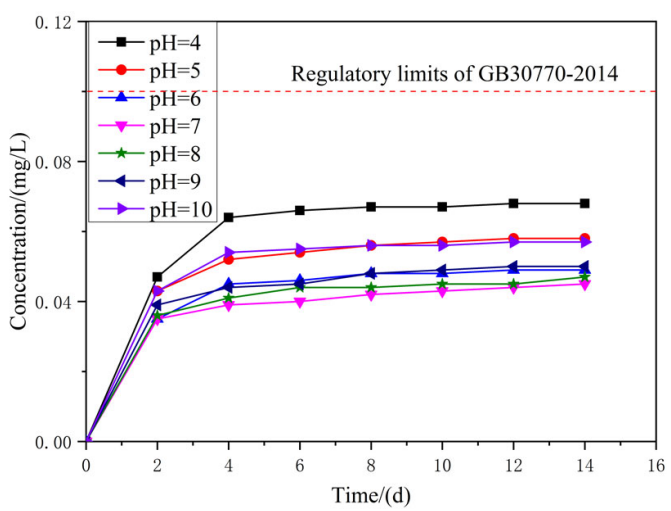

(b)

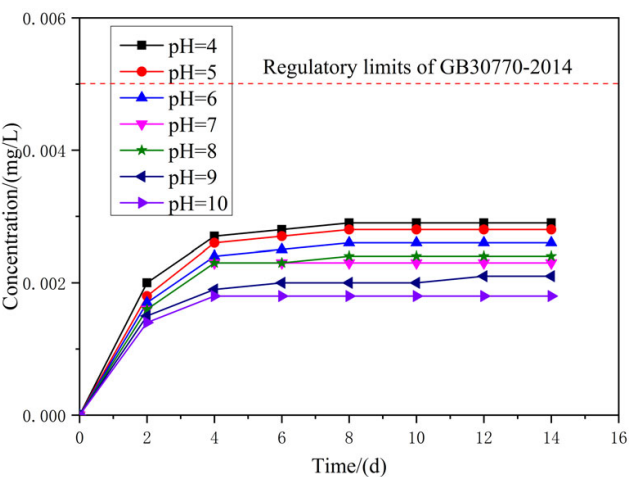

(c)

Figure 10. Leaching test result of heavy metals in ATCA concrete (unit: mg/L): (a) leaching of Sb; (b) leaching of As; (c) leaching of $\mathrm{Hg}$.

As can be seen from the figure, $\mathrm{pH}$ has a great influence on the leaking of $\mathrm{Sb}, \mathrm{As}$, and $\mathrm{Hg}$ in the concrete. Figure $10 \mathrm{a}$ shows the test result of $\mathrm{Sb}$. When the $\mathrm{pH}$ is 4, 7, and 10, the concentration of $\mathrm{Sb}$ on the fourth day is respectively $0.247 \mathrm{mg} / \mathrm{L}, 0.206 \mathrm{mg} / \mathrm{L}$, and $0.245 \mathrm{mg} / \mathrm{L}$; on the eighth day it is respectively $0.266 \mathrm{mg} / \mathrm{L}, 0.218 \mathrm{mg} / \mathrm{L}$, and $0.265 \mathrm{mg} / \mathrm{L}$; and on the 14th day it is respectively $0.269 \mathrm{mg} / \mathrm{L}, 0.225 \mathrm{mg} / \mathrm{L}$, and $0.269 \mathrm{mg} / \mathrm{L}$. It can be seen that both acidic and alkaline conditions will promote the dissolution and release of $\mathrm{Sb}$ in the concrete. The concentration of Sb increases with time and reaches a steady state on the eighth day. When the $\mathrm{pH}$ is 4,7 , and 10, the concentration of $\mathrm{Sb}$ on the eighth day is $1.08,1.06$, and 1.08 times of that of the test value on the fourth day. 
As for As, the changing trend of the tested result is consistent with $\mathrm{Sb}$, illustrated in Figure $10 \mathrm{~b}$. When the $\mathrm{pH}$ is 4,7 , and 10, the concentration of As on the fourth day is $0.064 \mathrm{mg} / \mathrm{L}, 0.039 \mathrm{mg} / \mathrm{L}$, and $0.054 \mathrm{mg} / \mathrm{L}$, respectively; on the eighth day it is $0.067 \mathrm{mg} / \mathrm{L}$, $0.042 \mathrm{mg} / \mathrm{L}$, and $0.056 \mathrm{mg} / \mathrm{L}$, respectively; and on the 14 th day it is $0.069 \mathrm{mg} / \mathrm{L}, 0.045 \mathrm{mg} / \mathrm{L}$, and $0.058 \mathrm{mg} / \mathrm{L}$, respectively. When the $\mathrm{pH}$ is 4,7 , and 10 , the concentration of As on the eighth day is $1.05,1.08$, and 1.04 times of that of the test value on the fourth day.

While the test results of $\mathrm{Hg}$ shows a different vibrational tendency, illustrated in Figure 10c. When the $\mathrm{pH}$ is 4,7 , and 10, the concentration of $\mathrm{Hg}$ on the fourth day is $0.0027 \mathrm{mg} / \mathrm{L}, 0.0023 \mathrm{mg} / \mathrm{L}$, and $0.0018 \mathrm{mg} / \mathrm{L}$, respectively; the concentration on the eighth day is $0.0029 \mathrm{mg} / \mathrm{L}, 0.0023 \mathrm{mg} / \mathrm{L}$, and $0.0018 \mathrm{mg} / \mathrm{L}$, respectively. After the eighth day, there is almost no change in concentration of $\mathrm{Hg}$. It can be seen that the concentration of $\mathrm{Hg}$ decreases with $\mathrm{pH}$ value increases. Therefore, the acidic condition will promote the dissolution and release of $\mathrm{Hg}$ in the concrete, while the alkaline condition will inhibit the leaking of $\mathrm{Hg}$ in the concrete.

Under varying conditions of $\mathrm{pH}$ range 4-10, the concentrations of $\mathrm{Sb}, \mathrm{AS}$, and $\mathrm{Hg}$ reach a steady state on the eighth day. Moreover, on the 14th day, the maximum concentrations of $\mathrm{Sb}, \mathrm{AS}$, and $\mathrm{Hg}$ are $0.266 \mathrm{mg} / \mathrm{L}, 0.067 \mathrm{mg} / \mathrm{L}$, and $0.029 \mathrm{mg} / \mathrm{L}$, respectively. While the regulatory limits of $\mathrm{Sb}, \mathrm{AS}$, and $\mathrm{Hg}$ are respectively $0.3 \mathrm{mg} / \mathrm{L}, 0.1 \mathrm{mg} / \mathrm{L}$, and $0.05 \mathrm{mg} / \mathrm{L}$. It is illustrated that all the test results are less than the regulatory limits. Therefore, the ATCA concrete can be considered as a non-hazardous material.

\section{Conclusions}

The chemical composition and mechanical properties of antimony tailing waste rock (ATWR), quality of antimony tailing coarse aggregate (ATCA), and leaching performance of ATCA concrete are studied in this work. Polarizing microscope and X-ray diffraction (XRD) analysis illustrated that the essential mineral of ATWR was quartz $\left(\mathrm{SiO}_{2}\right)$ and the lithology of ATWR was quartzite. The mechanical behavior such as cubic compressive strength, splitting tensile strength, compressive elastic modulus of ATWR and natural rock (NR) were studied simultaneously. The results show that the cubic compressive strength, splitting tensile strength, and prism compressive elastic modulus of ATWR are $1.31,2.22$, and 1.40 times of that of NR's, respectively. Therefore, the mechanical behavior of ATWR is superior to that of NR. It is demonstrated that all of the quality control indices of ATCA meet the requirements of the current industry standards of China. Moreover, ATCA possesses excellent abrasion resistance performance, thus it can be inferred that ATCA may be applied in concrete pavement. The leaching of main heavy metals including $\mathrm{Sb}, \mathrm{As}, \mathrm{Hg}, \mathrm{Pb}, \mathrm{Cd}$, and $\mathrm{Zn}$ in ATCA concrete under different $\mathrm{pH}$ conditions are below the regulatory limits. The ATCA concrete can be considered as a non-hazardous material.

A practical case study shows that the use of ATCA can save about $79 \%$ of the cost (¥70.224 million yuan, \$10.871 million dollars) and reduce about $15,000 \mathrm{~m}^{2}$ land occupation for stacking ATWRs. Utilizing ATCA in concrete provides a new way for reusing ATWRs, obtaining significant environmental and economic benefits. It should be noted that there is much future research work to do. The microstructural structure, the bonding with cement paste of ATCA concrete, and the static and fatigue performance of ATCA structure should be investigated.

Author Contributions: Conceptualization, J.W. and L.Z.; methodology, J.W. and L.L.; validation, J.W., L.L., and B.L.; formal analysis, L.Z., L.L. and B.L.; writing-original draft preparation, J.W. and L.Z.; writing-review and editing, J.W., R.D. and D.S.; project administration, R.D. and D.S.; funding acquisition, J.W. All authors have read and agreed to the published version of the manuscript.

Funding: This research was funded by the National Nature Science Foundation of China (Grant No.: 51408218,42102083 ), the Hunan Nature Science Foundation of China (grant No. 2020JJ4310), and the Hunan Education Department (Grant No.: 18A202).

Institutional Review Board Statement: Not applicable.

Informed Consent Statement: Not applicable. 
Data Availability Statement: The data presented in this study are available on request from the corresponding author.

Conflicts of Interest: The authors declare no conflict of interest.

\section{References}

1. Deng, R.; Tang, Z.; Hou, B.; Ren, B.; Hursthouse, A. Microbial diversity in soils from antimony mining sites: Geochemicalcontrol promotes species enrichment. Environ. Chem. Lett. 2020, 18, 911-922. [CrossRef]

2. Aduriz, H.R.; Bodnariuk, P.; Coq, B.; Figueras, F. Alumina-supported bimetallics of palladium alloyed with germanium, tin, lead, or antimony from organometallic precursors: I. Preparation and characterization. J. Catal. 1989, 119, 97-107. [CrossRef]

3. Krishna, L.; Lalonde, A.D.; Moran, P.D. Increase in the thermoelectric power produced by mechanically alloyed Pb1x Snx Te due to the presence of $15 \mathrm{~nm}$ Sno2 inclusions. J. Appl. Phys. 2011, 110, 8. [CrossRef]

4. Liu, S. The further processing antimony products in china. Multipurp. Util. Miner. Resour. 2003, 1, 29-32.

5. Fei, J.; Min, X.; Wang, Z.; Pang, Z.; Liang, Y.; Ke, Y. Health and ecological risk assessment of heavy metals pollution in an antimony mining region: A case study from south china. Environ. Sci. Pollut. Res. Int. 2017, 24, 27573-27586. [CrossRef] [PubMed]

6. He, M. Distribution and phytoavailability of antimony at an antimony mining and smelting area, Hunan, China. Environ. Geochem. Health 2007, 29, 209-219. [CrossRef] [PubMed]

7. Liu, F.; Le, X.C.; McKnight-Whitford, A.; Xia, Y.; Wu, F.; Elswick, E.; Johnson, C.C.; Zhu, C. Antimony speciation and contamination of waters in the Xikuangshan antimony mining and smelting area, China. Environ. Geochem. Health 2010, 32, 401-413. [CrossRef] [PubMed]

8. Fu, Z.; Wu, F.; Mo, C.; Deng, Q.; Meng, W.; Giesy, J.P. Comparison of arsenic and antimony biogeochemical behavior in water, soil and tailings from Xikuangshan, China. Sci. Total Environ. 2016, 539, 97-104. [CrossRef]

9. Gebel, T.; Christensen., S.; Dunkelberg, H. Comparative and environmental genotoxicity of antimony and arsenic. Anticancer Res. 1997, 17, 2603-2607.

10. Hammel, W.; Debus, R.; Steubing, L. Mobility of antimony in soil and its availability to plants. Chemosphere 2000, 41, 1791-1798. [CrossRef]

11. Krachler, M.; Zheng, J.; Koerner, R.; Zdanowicz, C.; Fisher, D.; Shotyk, W. Increasing atmospheric antimony contamination in the northern hemisphere: Snow and ice evidence from devon island, arctic canada. J. Environ. Monit. 2005, 7, 1169-1176. [CrossRef] [PubMed]

12. Hiller, E.; Lalinská, B.; Chovan, M.; Jurkovič, L'.; Klimko, T.; Jankulár, M.; Hovorič, R.; Šottník, P.; Fl’aková, R.; Ženišová, Z.; et al. Arsenic and antimony contamination of waters, stream sediments and soils in the vicinity of abandoned antimony mines in the western carpathians, slovakia. Appl. Geochem. 2012, 27, 598-614. [CrossRef]

13. Mori, C.; Orsini, A.; Migon, C. Impact of arsenic and antimony contamination on benthic invertebrates in a minor corsican river. Hydrobiologia 1999, 392, 73-80. [CrossRef]

14. Okkenhaug, G.; Zhu, Y.; He, J.; Li, X.; Luo, L.; Mulder, J. Antimony (Sb) and arsenic (As) in Sb mining impacted paddy soil from Xikuangshan, China: Differences in mechanisms controlling soil sequestration and uptake in rice. Environ. Sci. Technol. 2012, 46, 3155-3162. [CrossRef]

15. Zhou, S.; Hursthouse, A. The impact of physical properties on the leaching of potentially toxic elements from antimony ore processing wastes. Int. J. Environ. Res. Public Health 2019, 16, 2355. [CrossRef] [PubMed]

16. Jiada, W. Antimony vein deposits of China. Ore Geol. Rev. 1993, 8, 213-232. [CrossRef]

17. Zhou, S.; Andrew, H.; Chen, T. Pollution characteristics of Sb, As, Hg, Pb, Cd and Zn in soils from different zones of Xikuangshan antimony mine. J. Anal. Methods Chem. 2019, 2019, 2754385. [CrossRef] [PubMed]

18. Zhang, J.; Deng, R.; Ren, B.; Hou, B.; Hursthouse, A. Preparation of a novel $\mathrm{Fe}_{3} \mathrm{O}_{4} / \mathrm{HCO}$ composite adsorbent and the mechanism for the removal of antimony (III) from aqueous solution. Sci. Rep. 2019, 9, 13021. [CrossRef]

19. Sun, J.; Wang, Y.; Liu, S.; Dehghani, A.; Wang, X. Mechanical, chemical and hydrothermal activation for waste glass reinforced cement. Constr. Build. Mater. 2021, 301, 124361. [CrossRef]

20. Ferreira, L.; Brito, J.D.; Saikia, N. Influence of curing conditions on the mechanical performance of concrete containing recycled plastic aggregate. Constr. Build. Mater. 2012, 36, 196-204. [CrossRef]

21. Sun, J.; Lin, S.; Zhang, G.; Sun, Y.; Wang, X. The effect of graphite and slag on electrical and mechanical properties of electrically conductive cementitious composites. Constr. Build. Mater. 2021, 281, 122606. [CrossRef]

22. Thomas, S.T.; Damare, A.; Gupta, R.C. Strength and durability characteristics of copper tailing concrete. Constr. Build. Mater. 2013, 48, 894-900. [CrossRef]

23. Sharma, R.; Khan, R.A. Sustainable use of copper slag in self compacting concrete containing supplementary cementitious materials. J. Clean. Prod. 2017, 151, 179-192. [CrossRef]

24. Huang, X.; Ni, W.; Wang, Z.; Zhu, L. Preparation of autoclaved aerated concrete using copper tailings and blast furnace slag. Constr. Build. Mater. 2011, 27, 1-5. [CrossRef]

25. Zhou, G.Y.; Li, W.; Chen, Y.; Song, Y. Study on recovery of lead-zinc tailing ore by electrochemical flotation. Appl. Mech. Mater. 2014, 3547, 1451-1454. [CrossRef]

26. Onuaguluchi, O.; Eren, O. Recycling of copper tailings as an additive in cement mortars. Constr. Build Mater. 2012, 37, 723-727. [CrossRef] 
27. Choi, Y.W.; Kim, Y.J.; Choi, O.; Lee, K.M.; Lachemi, M. Utilization of tailings from tungsten mine waste as a substitution material for cement. Constr. Build. Mater. 2009, 23, 2481-2486. [CrossRef]

28. Nie, Y.; Liu, S.; Dai, Q. Mineral processing experiment of quartz from gold ore tailing. Adv. Mater. Res. 2013, $2262,2475-2477$. [CrossRef]

29. Gayana, B.C.; Chandar, K.R. Sustainable use of mine waste and tailings with suitable admixture as aggregates in concrete pavements-A review. Adv. Concr. Constr. 2018, 6, 221-243.

30. Zhao, S.; Fan, J.; Sun, W. Utilization of iron ore tailings as fine aggregate in ultra-high performance. Constr. Build. Mater. 2014, 50, 540-548. [CrossRef]

31. Lv, X.; Shen, W.; Wang, L.; Dong, Y.; Zhang, J.; Xie, Z. A comparative study on the practical utilization of iron tailings as a complete replacement of normal aggregates in dam concrete with different gradation. J. Clean. Prod. 2019, 211, 704-715. [CrossRef]

32. Vijayaraghavan, J.; Jude, A.B.; Thivya, J. Effect of copper slag, iron slag and recycled concrete aggregate on the mechanical properties of concrete. Resour. Policy 2017, 53, 219-225. [CrossRef]

33. Wang, J.; Li, B.; Li, L.; Zuo, C.; Wang, Y. Feasibility Study of Antimony Waste Rock Coarse Aggregate High Strength Concrete. In Proceedings of the 17th Biennial International Conference on Engineering, Science, Construction, and Operations in Challenging Environments, Seattle, WA, USA, 19-23 April 2021.

34. Cocke, D. The binding chemistry and leaching mechanisms of hazardous substances in cementitious solidification/stabilization systems. J. Hazard. Mater. 1990, 24, 231-253. [CrossRef]

35. Sanchez, F.; Gervais, C.; Garrabrant, A.; Barna, R.; Kosson, D. Leaching of inorganic contaminants from cement-based waste materials as a result of carbonation during intermittent wetting. Waste Manag. 2002, 22, 249-260. [CrossRef]

36. Moszkowicz, O. Study of mineralogy and leaching behavior of stabilized/solidified sludge using differential acid neutralization analysis: Part I: Experimental study. Cem. Concr. Res. 2009, 39, 501-509.

37. Argane, R.; Benzaazoua, M.; Hakkou, R.; Bouamrane, A. Reuse of base-metal tailings as aggregates for rendering mortars: Assessment of immobilization performances and environmental behavior. Constr. Build. Mater. 2015, 96, 296-306. [CrossRef]

38. Barna, R.; Moszkowicz, P.; Gervais, C. Leaching assessment of road materials containing primary lead and zinc slags. Waste Manag. 2004, 24, 945-955. [CrossRef]

39. Zhou, Y.; Duan, X.; Chen, T.; Yan, B.; Li, L. Mechanical Properties and Toxicity Risks of Lead-Zinc Sulfide Tailing-Based Construction Materials. Materials 2021, 14, 2940. [CrossRef]

40. Onuaguluchi, O.; Eren, Ö. Copper tailings as a potential additive in concrete: Consistency, strength and toxic metal immobilization properties. Indian J. Eng. Mater. Sci. 2012, 19, 79-86.

41. Huang, X.C.; Xu, X.D.; Chen, Q.N.; Liu, Y.F. Reliability analysis of the anti-sliding of a retaining wall subjected to seismic loads. Proc. Inst. Mech. Eng. Part O J. Risk Reliab. 2021, 235, 853-862.

42. MOTOC. Test Methods of Rock for Highway Engineering (JTG E41-2005); Ministry of Transport of China: Beijing, China, 2005.

43. Goodman, R.E. Introduction to Rock Mechanics, 2nd ed.; Wiley: Berkeley, CA, USA, 1989; pp. 151-184.

44. Huang, X.C.; Zhou, X.P. Reliability analysis of a large-scale landslide using SOED-based RSM. Environ. Earth Sci. 2017, 76, 794. [CrossRef]

45. Wang, J.; Tang, S.; Zheng, H.; Zhou, C.; Zhu, M. Flexural behavior of a 30-meter full-scale simply supported prestressed concrete box girder. Appl. Sci. 2020, 10, 3076. [CrossRef]

46. Zhou, C.; Li, L.; Wang, J. Modified bar simulation method for shear lag analysis of non-prismatic composite box girders with corrugated steel webs. Thin-Walled Struct. 2020, 155, 106957. [CrossRef]

47. CNSMC. Pebble and Crushed Stone for Constrction (GB/T 14685-2011); China National Standardization Management Committee: Beijing, China, 2005.

48. MOEP. Emission Standards of Pollutants for Stannum, Antimony and Mercury Industries (GB 30770-2014); Ministry of Environmental Protection: Beijing, China, 2014. 